\title{
BURIED ALIVE: THE PHENOMENON OF APPARENT DEATH IN ESTONIAN TRADITION
}

\author{
Eda Kalmre \\ Senior Research Fellow \\ Department of Folkloristics \\ Estonian Literary Museum, Estonia \\ eda.kalmre@folklore.ee
}

\begin{abstract}
Hardly any other folklore subject or motif can offer a more colourful bouquet in genre than apparent death, ranging from fairy tales and romantic legends to rumours, ballads, and jokes. The historical origin of stories of apparent death extends back to antiquity, probably also relying on some true events; however, the formation and spread of folktales on this subject falls into the Enlightenment period in Europe. The emergence and development of this topic relate to medical and religious practices, journalism and literature. The article focuses on the traditional context of apparent death in eighteenth-nineteenthcentury Europe, including Estonia.
\end{abstract}

Keywords: apparent death, Enlightenment, funeral, legend, premature burial, rumour, seemingly dead

As a metaphor, the Estonian word varjusurm (Ger. Scheintod, Scheintote) is still in active use in Estonian, meaning 'seemingly dead', 'apparently dead', 'dormant', 'death trance', or 'lethargy'. Today the word is used to signify something that exists but is dysfunctional. Consider, for example, the following random headlines in the Estonian media: aktsiafondid on varjusurmas 'stock funds are apparently dead', hüpnoosravi Eestis on varjusurmas 'hypnosis as a form of treatment is apparently dead in Estonia', etc. At the same time, the direct meaning of the word is not entirely forgotten or obsolete among the general public. Time and again, newspapers publish translations of news reports of dubious truth value about the sudden resurrection of someone who has been declared dead. These sensational reports are likely to migrate from one publication to another and from one country to another via online media, whereas those who publish them often do not bother to check if they are true. 
In Europe, the subject of identifying death and the phenomenon of apparent death have been discussed for centuries. Real or potentially real cases of the dead returning to life have been addressed in oral lore, literature, early journalism, as well as in medical literature. The first (and by far the most frequently quoted) reference to such stories can be found in Plato's Republic. Here Plato recounts the story of an Armenian soldier who was slain in battle. When his body was picked up ten days later, it was intact and so was taken home, but when the body was placed on the funeral pyre to be burnt, he returned to life (Bondeson 2001: 19). The monograph Buried Alive: The Terrifying History of Our Most Primal Fear by Jan Bondeson, professor at the University of Wales College of Medicine, discusses the fear that once overcame humanity, and can be considered one of the most exhaustive modern studies of the phenomenon of Scheintod, or apparent death, taking into account many sources and aspects of different fields. That same year as Bondeson's book, another rather comprehensive historical and folkloristic monograph appeared, titled Erzählungen über den Scheintod. Faktizität und Fiktionalität in medizinischen Fallberichten (2001) by Ines Köhler-Zülch. Relying on the thorough approaches by Bondeson and Köhler-Zülch in my paper, I will provide an insight into the topic of apparent death through the lens of folkloric, literary, medical, religious, and journalistic sources, focusing on this material in Estonia from the eighteenth to the nineteenth century as well as the first decades of the twentieth century.

\section{APPARENT DEATH FROM THE PERSPECTIVE OF MEDICINE}

Apparent death is a popular term marking a deep sleep-like state that in previous centuries not even doctors were always able to diagnose. In such a state, an individual's metabolism is reduced to a minimum and breathing and heart activity cannot be detected by external observation. The state could last for days or even for weeks. Such symptoms are quite typical of several modern-day diseases, or cases of significant blood loss or intoxication (by opium or chloroform), as well as sometimes occurring in new-born babies. Fairy tales about Sleeping Beauty are probably based on this very phenomenon. Certain illnesses, such as diabetes, epilepsy, etc., can cause a person to lapse into a coma, then seemingly returning to life. ${ }^{1}$ Modern medicine refers to such autoresuscitation using a biblical term - the Lazarus syndrome. In 1968, an important decision regarding confirmation of death was made with the advent of the so-called Harvard criteria on brain death, i.e. the cessation of the functions of the entire brain. Patients in this irreversible state are defined as being dead, and their organs 
become available for harvesting and transplant (Lehtmets \& Elmet 2013). Jan Bondeson (2001: 270-272) notes that even after the Harvard criteria were established, the doubts and fear about returning to life on the operating table while being harvested for organs persisted for at least another decade, as the debate among medical professionals continued, leading to special tests being conducted for additional examination, such as using EEG to test bioelectric signals of the brain. Journalists too played a role in instigating such doubts, and it was only in the 1980s and 1990s that brain death became a generally accepted measure.

\section{THE ENLIGHTENMENT-ERA BREAKTHROUGH: MEDICINE AND PRACTICES THROUGH THE CENTURIES}

In the Enlightenment era, taphephobia, or the fear of being buried alive, one of the most primal human fears, suddenly became very topical as a result of the combination of several factors.

In seventeenth-century medicine, pagan myths, religious legends, and popular beliefs existed alongside science-based ideas.

Death was defined as a state where life was extinct and the soul had left the body; a person could be either dead or alive, and no concept existed of a process of dying. Death was regarded as a whole supernatural, obscure phenomenon, outside the limits of rational analysis. (Bondeson 2001: 22-23)

During the seventeenth-century plague, doctors and relatives of the sick were accused of killing people or deliberately burying them alive (Slack 1985: 274-275). However, during that century views on death and dying began to change. In the eighteenth century, evidence of the fear of apparent death emerged, for example in the burial sites of plague victims. During a grave excavation in Marseilles, corpses were discovered with long needles driven in their fingers as a form of verification that the people were indeed dead. This means of verifying death was later widely used (Bondeson 2001: 32-33). Primarily owing to the epidemics, many doctors learned the fatal consequences of burying the dead prematurely to prevent the spread of the disease. In the eighteenth century, uncertainty over what signs showed life and death, and the phenomena accompanying the process of dying turned into a problem for medical science, to which solutions were sought (as noted above) as late as the twentieth century. The line between life and death became blurred, and the transient state, apparent death, was 
defined, although its actual identification proved too challenging for both educated medical practitioners and - even more so - for the uneducated peasant. Even as late as the nineteenth century, the stench of putrefaction was considered the only efficient medical proof of someone's death. At the time, medicine and healthcare policies were intended to instil fear and warn people against being buried alive. As additional measures, attempts were made to observe the corpse and legally extend the time of burial (Köhler-Zülch 2012: 179).

In the eighteenth and nineteenth centuries, medicine was developing and exploring. During this time, many important discoveries were made. Tallinn's first chickenpox vaccinations took place in the first years of the nineteenth century; in the 1830s, a distinction was made between syphilis and gonorrhoea (see Gustavson 1969: 47; 1979: 12). In the nineteenth century, the movement against premature burial gained momentum in Europe. Among other things, relevant societies were established, one of the most influential among them being the London Association for the Prevention of Premature Burial, founded in 1896. The society published newspaper stories about people buried alive, seemingly dead women giving birth, etc., and attempted to have the British Parliament pass a bill to prevent burial or disposal of a body without a medical certificate issued by a doctor, and to ensure that no such certificate was issued without a thorough inspection and examination of the body. ${ }^{2}$ In fact, the emergence of the topic of apparent death coincided with the general aspirations of the governing elite, intellectuals, doctors and economic and religious circles of the Enlightenment era to educate the general public and to make the world a better place.

Case reports, describing people who had returned to life or had been mistakenly buried after appearing to be dead, were used to provide better examples, emphasise the seriousness of the problem, and present the material in a more attractive way. Among the most famous and influential medical works that shaped attitudes, instilled fear and confusion, and spread folklore in eighteenth- and nineteenth-century Europe, were the volumes of Dissertation sur l'incertitude des signes de la mort et l'abus des enterremens et embaumemens précipités (vols. 1-2, 1742-1745), ${ }^{3}$ and Abhandlung von der Ungewißheit der Kennzeichen des Todes und dem Mißbrauche der mit übereilten Beerdigungen und Einbalsamirungen vorgeht (1754) by Jacques Jean Bruhier, and the socalled dictionary of apparent death, Der Scheintod oder Sammlung der wichtigsten Thatsachen und Bemerkungen darüber, in alphabetischer Ordnung in 1808 by the prominent Doctor Christoph Wilhelm Hufeland (1762-1836) ${ }^{4}$ (see Bondeson 2001; Köhler-Zülch 2001).

Ines Köhler-Zülch and Jan Bondeson demonstrate in their studies how facts and fiction, folklore and literary adaptations intermingled in these supposed case 
reports. Both authors mention that in Europe in the Age of Enlightenment, the topic of apparent death remained popular because of advancements in medicine, journalism, literature and folklore, church and religion. All these institutions strove to inform and educate people, and continued to retell old and new stories about cases of possible or actual apparent death. At the height of this debate, rules and laws regulating death and burial were officially adopted. In fact, so many printed publications at the time instigated the fear of apparent death that by the mid-nineteenth century it had evolved into a hysteria (see KöhlerZülch 2001). Special hospitals were built to observe dead bodies, customised coffins had bells attached to them, etc. Many historians, when contemplating the fear of premature burial, which gripped Europe in the mid-eighteenth century, have admitted that this fear was a kind of by-product of the dechristianisation process (see Ariès 1991: 399-401; Bondeson 2001: 77).

Many people had begun to question the traditional Christian dogma, and the secular rationalism left an emotional vacuum for those who had to confront the thought of death without the hope of paradise. This led to an increased fear of death. ...people became concerned about what happened to their dead-or perhaps not so dead-bodies: If they did not enter a better world in the odor of sanctity, what befell them? The physical torments of a premature burial - the ghoulish minutiae of gnawed hands, bruised heads and beaten bodies that recur in Bruhier's books - may be taken to represent some kind of secularized hell. (Bondeson 2001: 77)

The most active movement for preventing premature death was in Germany, where Hufeland was also active. In his hometown, Weimar, the first Leichenhaus, a waiting mortuary, was built as early as in 1792. But the movement for preventing premature death had a significant effect also in France, England, and elsewhere. In Germany, however, most waiting mortuaries had either been demolished or had changed their purpose by the mid-nineteenth century, although they continued to operate in major cities, such as Frankfurt, Mainz, Munich, and Berlin. Similar new institutions were still being opened in Düsseldorf, Stuttgart, and Hamburg in the 1870s (Bondeson 2001: 90-91, 104, see also 88-117).

Many famous people, such as novelists Hans Christian Andersen and Fyodor Dostoyevsky, and chemist Alfred Nobel and others, lived in fear of being buried alive. Nikolai Gogol (1809-1862) was terrified of being buried while being lethargic, and rumours later suggested that this is exactly what happened to him. According to the rumours, when Gogol's grave was opened for reburial in 1931, his body had moved, and there were scratch marks inside the coffin's 
lid. Although there were alternative explanations, the speculation about him having been buried alive still lingers in many works on Gogol's life and death (Lovejoy 2015). The topic of being buried alive received lively discussion in the works of many famous nineteenth-century authors, for example Gottfried Keller (1819-1890) in his poem "Lebendig begraben", Edgar Allan Poe (1809-1849) in The Premature Burial, etc.

\section{THE TOPIC OF APPARENT DEATH IN ESTONIA}

An analysis of various sources reveals that this fear and the topic in general arrived somewhat later in Eastern Europe, including Estonia, and did not gain perhaps the same momentum as elsewhere. Still, the topic was known here and was discussed in daily life, in newspapers, in law, and, certainly, in folklore in the form of legends and rumours.

Articles about various cases of suspected apparent death were written not only in Estonia but also in neighbouring countries. For example, in the $1880 \mathrm{~s}$, several articles on the subject were published in a Russian medical journal. One of these describes a case of exhumation because the dead body had been seen with tears upon his face at the funeral. Village or parish priests often took on doctor's responsibilities, which included pronouncing death. To provide the village priests with the knowledge of how to confirm death, a special magazine containing such advice was designed for the priests by the Kiev Theological Academy in the nineteenth century (Warner 2000: 73-74). Information was also shared with peasants. The first printed publications in the homes of Estonian peasants were calendar books, and already eighteenth-century calendars contained instructions on how to resuscitate people in the case of hypothermia, drowning, and apparent death. Such instructions were published, for example, in the Eesti-Ma Rahva Kalender (Estonian Peasants' Calendar) and Ramma Josepi Hädda-ja Abbi-ramat (Ramma Josep's Emergency Manual) by Friedrich Gustav Arvelius in the early 1790s (see Martsoo 2007: 11).

In Estonia, the church regarded hasty funerals and wakes for the deceased as a pagan phenomenon. In this context, it makes sense that clerical circles were particularly keen on inciting a fear of being buried alive, often by opposing and rejecting the traditional family-centred death and funeral traditions.

The church had every reason to be discontented. Several works analysing the funeral traditions of Estonians and their kinsfolk (Reiman 1915; Mikkor 1994, 1995; etc.) reveal that Estonians were not particularly eager to observe Christian traditions, even though they had converted to the church centuries 
before. Merike Lang, who has studied northeast Estonian funeral culture, has argued, relying on some sixteenth to nineteenth-century sources (David Dubberich, Johann Wilhelm Ludwig von Luce) that, in reality, people tried to bury the dead as soon as possible (Lang 2004: 84 ). There were probably many reasons for this, one being poverty, because people attending a wake had to be fed, while another was the time away from work that a wake entailed. The church tried to instil new content in the ritual of the wake (Rimpiläinen 1971: 207, 259). In 1799, a church law was adopted prohibiting the washing of the dead, or apparently dead, before rigor mortis had completely set in, or before all vital signs were lost, and obliging at least a three-day delay to the funeral (Rosenplänter 1823).

It is safe to assume that in the nineteenth century the fear of being buried alive was part of everyday life. People wrote about it, spoke about it, and spread rumours and longer tales with traditional plots (migratory legends) about being apparently dead or buried alive. Certainly, people also joked about the subject, and these romantic tales inspired popular ballads. Among the most extreme measures against being buried alive were the abovementioned special waiting mortuaries, and patent coffins with special signalling devices. Such material has not been recorded in writing, but according to an oral report, a coffin with a signalling device was known to have been used at Raadi cemetery in Tartu. ${ }^{5}$

In the $1860 \mathrm{~s}$, a waiting mortuary was built near the railway station in Tallinn for the inheritance, specially assigned for this purpose, of an eccentric doctor Heinrich Heinrichsen (1781-1855), who had lived in the area. ${ }^{6}$ Heinrichsen had been interested in hypnosis and homeopathy and, throughout his life, had struggled with the fear of being buried alive (Gustavson 1979: 204; Vende 1990: 50-51). This peculiar mortuary in Tallinn has been described in a humorous tone by Werner Bergengruen (1892-1964) in his short story "Die wunderliche Herberge" (Bergengruen 1966).

\section{THE TOPIC OF APPARENT DEATH IN ESTONIAN FOLKLORE}

Some of the motifs and narrative plots surrounding the topic of apparent death are old and known all over the world. The earlier of the texts held in the Estonian Folklore Archives date back to the late 1880s while the most recent ones were recorded in 2000. The author of this article has also collected quite a number of such texts during annual fieldwork conducted each summer since 1986. This material also resulted in a review paper presented in 1988 (Kalmre 1988). 
Most of the Estonian tales about apparent death were collected in the latter half of the twentieth century. One of the possible reasons for this is that the majority of such material circulated as rumour in the early days of folklore collecting, i.e. the final decades of the nineteenth century and in the early twentieth century, meaning that the incidents seemingly occurred to a friend of a friend. Because of the criteria that folklore collecting was based on at the time, collectors could not recognise the traditional nature of the tales and regarded them as information that reflected daily life, especially because the nineteenth-century newspapers published similar news about supposedly real cases of apparent death. Folkloristic fieldwork materials suggest that the tradition of tales of apparent death remained in living memory in the final decades of the twentieth century. The following extracts from the accounts recorded in the 1970s and 1980s and preserved in the Estonian Folklore Archives (RKM) are indicative of this:

My mother's relative lapsed into apparent death during childbirth.

It happened right here, in Lelle.

When my grandmother saw someone who had passed away in her sleep, she believed the person was apparently dead.

When my uncle passed away, my father was not sure that he was completely dead and checked with a mirror to see if he was still breathing. Some people have been apparently dead, you know.

A midwife once asked to have her veins sliced to avoid being apparently dead.

In childhood, these stories about apparent death were quite scary; people told them often.

In my youth, it was said that a dead body should not be kept at home before the funeral; instead, it has to be taken to the hospital and the burial postponed for several days.

Leaving aside the fairy tales featuring elements of apparent death (Sleeping Beauty aka Little Briar Rose, Snow White), the Estonian tradition contains four main plot variations according to tale type indices (Uther 2004; Simonsuuri 1987). Firstly, 'A woman feigns death', or in the Estonian material rather 'The seemingly dead bride' (885A) is categorised as a so-called short narrative folktale with the following plot: a young woman (or princess) falls in love with an older man. But her parents force her to marry another. On her wedding 
day, the woman lapses into apparent death (faints, chokes on something). The groom hears voices from her grave, opens the grave, rescues the maiden and they get married. Alternatively, the maiden is saved by a grave robber. In some variants, a wax figure is made after the maiden is buried. The story has Chinese origins, while the European versions date back to the Middle Ages (e.g., Decameron, 4th tale of Day 10; see Boccaccio 2004: 609-614; Uther 2004: 510). This plot has also been called a romance and has been recorded most numerously in southeastern Estonia, more specifically the Seto region.

Secondly, 'A seemingly dead person reawakens' (990; Uther 2004: 617 or C1901 according to Finnish legend repertoire, see Simonsuuri 1987: 67). A woman falls ill during a pandemic and lapses into a deathlike state. She is placed in a grave with a valuable ring. A gravedigger comes to rob the grave, but as he pulls the ring from her finger the woman returns to life, goes home, and lives a long life. In some cases, she marries the grave robber (merges with plot 885A). This tale was documented in the late Middle Ages (cf. Decameron, 5th tale of Day 2 and 4th tale of Day 10, Boccaccio 2004: 93-101, 609-614) and is known in most parts of the world (Uther 2004: 618)7. These two plots usually have a happy ending with the seemingly dead person brought back to life.

The third plot, 'A pregnant woman lapses into seeming death' (C1921, see Simonsuuri 1987) does not end happily: a woman is buried, gives birth in the grave and dies. In these tales, the evidence of being buried after apparent death was the child (or children) born in the grave. The voices heard from the grave and the bones of children found in the coffin after exhumation were proof of this horrible event.

It happened right here, in Lelle, in Nassa's house. There was this young woman, and she died. She was also pregnant. And all the time she kept appearing in her husband's and parents' dreams. And she was telling them things in their dreams and they dug her up. She had given birth to a child in that grave. It is a miracle how she could have survived there for that long without air.

(RKM II 402, 164(19) < Juuru, Ingliste parish, Palu village - A. Korb $<$ Aliide Kallis, 79 years (1987))

In some cases, the seemingly dead bride and the not-quite-dead pregnant woman giving birth merge into one. In the narrative variants given here, the protagonist of the tales is a young woman. Even though these traditional tales had all the features needed to spread as widely as the case reports of eighteenth- and nineteenth-century medical literature, they were also popular sources of fiction. In fact, the line between the two genres was somewhat vague, as suggested 
by the foreign-sounding names of the characters, the romantic plot, etc. The second plot given here is known outside Estonia as 'The lady with the ring'. From the fourteenth to the nineteenth century, the story, adapted to the local situation and featuring local characters, was one of the most popular migratory legends in many European towns. For example, in Shankill cemetery in Ireland a tomb monument has been erected for Lady Margorie McCall, who was reportedly buried alive and rescued from the grave by grave robbers. In seventeenth- and eighteenth-century Germany, an analogous story is known from at least 19 towns (Wikipedia: Lady with the Ring; see also Bondeson 2001: 35-71). During the 1988 fieldwork in Puhja, I wrote down a sentimental account of events that allegedly happened in the town of Mitau, told by 83-year-old Hilda Pääsuke.

There was this manor lady once, from the town of Mitau. She died, and the funeral was held and all. But the cemetery guardian, he used to be very poor, had a dozen children or so. But the manor lady had a lavish funeral, and all this gold was placed in her grave, rings and all. So, he thought that he should take these. But he had a 12-year-old daughter who followed her father to the cemetery. After a while, she saw her father running back from the cemetery and going towards the pond. ... The girl asked where he was going. The father rushed into the pond. The daughter was holding her father by the hand, trying to calm him down. You see, he had dug up the grave at the chapel to get the ring from the lady's finger. So, he took a knife and poked with its end, but he cut into her finger so that it bled and the lady woke up. The lady stood up and then returned, saying, hurry, the cemetery guardian is trying to drown himself. People were first frightened of her, believing that she was a ghost, but then realised that she was human and went to the pond. The 12-year-old girl had held her father until then. But she couldn't have done it much longer! So, they rescued the cemetery guardian. And later he told the manor lord that he did that because he was so poor. The lord was happy that he had got his wife back and gave the cemetery guardian a horse, a cow and a piglet, and a plot of land on top of it. It is a true story. The lady, whom my mother was serving, was also from Mitau - she told the story.

(RKM II 413, 483/5 (22))

These tales may be presented in a rather romantic tone, especially those about a wealthy baron's daughter marrying a poor grave robber who rescued her. In terms of early sentimental popular literature, which drew ideas from the social themes of general interest and from folklore, the focus on apparent death as 
a phenomenon was quite typical. The tales that have survived to the present day in the form of folktales and literature were often linked to some young lady of noble descent. In the Estonian tradition, one of the most famous women to give birth to a child while apparently dead was princess of Braunschweig, Auguste Friederike Luise, daughter of a Prussian duke, who is buried in Kullamaa Church. The princess was sent into exile to Koluvere Manor after becoming involved in court intrigues in St. Petersburg. In Estonia, the young princess's fate proved rather unfortunate. Local tradition still knows the legend of an unfortunate Friederike, who gave birth to a child after being buried alive (see Kaljund 2012). ${ }^{8}$

Estonian tradition also includes, although in smaller numbers, belief legends about an apparently dead person who returns to life before the funeral (C1931) but is forbidden to speak about what he or she saw in the state of death. The texts suggest that such a person usually dies within a year, or three or four years.

There used to be a house near the Rebuoja forest in Tammiku. And the master of the house died. His wife and five children were left behind. The wife was crying rivers and summoned the coffin makers. When the men arrived, the dead man returned to life and told them to bring three mouthfuls of bread, salt, and water. Then he told them: "Come back in three years." The man refused to speak about what he saw or where he was, when he was in the state of death. Or else he would die instantly. Three years later, the man died completely.

(RKM II 83, 151 (8) < Väike-Maarja - H. Muru > Valdo Mattisen, 86 years (1959))

While tales like the one above contained homogenous and stable (sometimes even complex) plot features representing so-called folkloric tale types, it was much more common that, against the background of general fear of the eighteenth and nineteenth centuries, stories about apparent death, and reawakening from apparent death, were spread as tall tales or rumours. These tales were generally short descriptions of unusual incidents that were associated with specific (local) people and cemeteries.

In Karijärve people said: she was eating chicken when a small bone got stuck in her throat. They started to bury her, went to the cemetery. And she was the mother of Mitt of Nosse. Well, they went with horses, it happened a long time ago. And the road was bumpy, and the bone came loose and they both came home together.

(RKM II 414, 177/8 (18) Puhja, Kaimi village - A. Korb < Alma Sütt 80 years (1988)) 
Of course, this is also very much reminiscent of a motif (E21.1) from Snow White: by shaking the poisoned piece of apple loose from the girl's throat the prince brings her back to life.

\section{THE TOPIC OF APPARENT DEATH IN NINETEENTH- AND EARLY TWENTIETH-CENTURY ESTONIAN NEWSPAPERS}

In Estonia, popular cautionary tales and warnings to delay funerals were also spread in the newspapers of the nineteenth century, and even of the first decades of the twentieth century. Already in 1806, an article warning against being buried alive was published in the second issue of the first Estonian-language weekly newspaper, Tarto maa rahwa Näddali-Leht (Tartu Country People's Weekly). The article emphasises the need to delay the burial of a dead body for three days because many people had already been buried alive. In this piece of writing, again, the stench of putrefaction is considered the most reliable sign of death:

The clearest sign indicating that someone is completely dead, is the stench of death, which everyone recognises. When the stench can be smelled, the dead body will start moving or swelling; and foam comes upon you and black and blue marks appear on the body. This is how long everyone must wait with the burial, when all that is seen. (Tannberg 1998: 167)

In order to solve the peasants' problems with labour and scarcity of food, the article in the weekly newspaper suggested that an elderly person in the village can be appointed to observe the death wake for a small remuneration and that those who visit the dead are not offered food and drink. The article also emphasised that, according to the law, funerals had to be delayed for three days (Issakov \& Peegel 1998: 137; Tannberg 1998: 166-167).

The newspapers also published longer tales based on legends and adapted to the local context. For example, the long story published in 1928 in Oma Maa is very similar to the story of Princess Auguste Friederike Luise of Koluvere manor and is categorised under the tale type 'A pregnant woman lapses into seeming death'. The tale recounts the story of a manor lord on Saaremaa who married, against his mother's wishes, a manor servant's daughter who lived near Tallinn. The young woman became pregnant, despite her husband having travelled away from home. Her due date arrived and since the young woman's mother-in-law did not take care of her, she fainted. Immediately the mother-inlaw had a coffin brought, and the young woman was laid in it. The mother-in-law nailed the coffin lid shut with her own hands and locked the room where the 
coffin was kept. The maids heard screaming and moaning from the room. But the mother-in-law had the coffin quickly buried. The young manor lord came home and was full of sorrow. He overheard maids talking about the screams and had the grave opened. The grave was opened, and the horrible story became known to all. The young woman was dead, her face was scratched and bleeding, with a dead baby at her feet. The cruel mother-in-law lost her mind and went raving mad (Oma Maa 1928). Even though the title of the article positions it in the past (õudne lugu minevikust, 'a horrible story from the past') and refers to it as a folktale from Saaremaa, the legend characteristically retains the necessary degree of credibility, made plausible by having a plot that involved local characters and places.

A survey of nineteenth- and early twentieth-century Estonian newspapers suggests that so-called true reports of the apparently dead were characteristic mainly of the nineteenth century, although the topic definitely captured the public imagination in the first decades of the twentieth century. ${ }^{9}$ In the second half of the nineteenth century, newspapers published dozens of short reports of cases that happened in Estonia. Often such 'news' spread from one media publication to another, until another publication proved that the story was not true. A rather typical example was a story about a 21-year-old woman from Kohava parish who had been buried alive. The story was initially published in the weekly Wesenberger Anzeiger and was translated for the Estonian media. In 1883, this short news report was published in several local papers: on 9 August (no. 32) in Wirulane (Viru Man) and on 10 August (no. 32) in Kündja (Plougher). In the next issue of Kündja, the following announcement was published, refuting the news: "From Rakvere. Dr. Voss, the county physician of Wiru County, refutes Wesenberger Anzeiger's news published in St. Petersburger Zeitung about the woman buried alive in Kohava" (Kündja 1883). In 1884, Wirulane published a story about a woman who had died twice: "We have received information that on 10 March an elderly mother, who had died twice, was buried in Laiuse cemetery" (Wirulane 1884a). A few days later, however, the news report was declared false: "In issue 12 of our newspaper, there was a message which had been sent to us to be published [but] in Laiuse parish, the old woman was not apparently dead but had died right away" (Wirulane 1884b). Of course, not all the rumours were refuted, such as the following: "In the Haapsalu area, people are speaking about an innkeeper who had been dead for a week and then returned to life" (Postimees 1887). It is safe to assume that these newspaper stories also spread by word of mouth, as rumour, and, in fact, journalism and folklore operated in synergy in this: newspapers published rumour, then what was published in the newspapers was spread as rumour. In addition to the 
above examples, news pieces about apparent death were also published in early twentieth-century newspapers such as Päevaleht (Daily) and Põhja Kodu (Northern Home).

Thus, we may agree that until the 1930 s, journalism was quite actively involved in the topic of apparent death, publishing various case reports and articles that educated the general public in the topic or discussed it as a medical phenomenon. The majority of the articles, however, were translated stories, such as "Varjusurm. Prof. Obolenski järele" (Apparent death. After Prof. Obolenski) (Eesti Postimees 1904); "Hirm elusalt maetud saada. Inglise lady, kes oma laibal laskis läbi lõigata kõri" (The fear of being buried alive: An English lady who had her throat cut after death) (Esmaspäev 1926); "Kas surnud on tõesti surnud?" (Are the dead really dead?) (Postimees 1926); "Varjusurma tont. Muumiate ja tinakambri laipade vereproov" (The spectre of apparent death: Blood tests on mummies and corpses in the lead chamber) (Postimees 1928a); "Lõpp varjusurmale. Inimelektri ime" (An end to apparent death: The miracle of human electricity) (Postimees 1928b).

\section{IN CONCLUSION}

Folktales, in their unique way, are the repository of the dreams of humanity. Today, many ideas that used to be expressed in dreams, such as flying carpets, seven-league boots, etc., have been realised in some form. However, the wondrous awakening of Snow White or Sleeping Beauty from their long sleep remains unresolved. The almost childlike idea of cheating death by prolonging the final end in a lethargic state, which has been expressed in folktales, is perhaps even more topical for humanity today than it was fifty or a hundred years ago. Such are the contributions of the modern scientists who explore the limits of life, for example, manned extended-duration space flights. Some steps have already been made in extending human life, for example the freezing of egg cells for future pregnancy is possible even in Estonia. Even now there are many private institutes and organisations around the world that specialise in cryonics, i.e. preserving the bodies of dead people or animals at low temperatures in the hope of resurrecting and restoring them to full health in the future. However, so far no cases are known in which a person in such a state has been revived. ${ }^{10}$

As a folklorist, I certainly argue that hardly any other topic or folktale has evolved into such an array of genres than that of apparent death, from folktales and romances to tall tales and rumours. This work, however, does not cover the ballads and jokes on apparent death that circulated in Europe and also emerged 
in the Estonian tradition, although in very few instances. From this perspective, tales about apparent death constitute a fascinating example of how the motifs established in the fictitious world of traditional folktales have spread into the real world of legends, where everything 'really' happens to 'real-life' people. The subject of apparent death and being buried alive has been and continues to be popular in modern works of pop culture, movies, and literature.

Apparently, this reciprocally functioning/feeding material on the topics of apparent death, which has emerged in various media (oral history, journalism, literature, written works on medicine, religion, and social politics), forms a discursive entity. Although associated with cults of religion and the dead and based on myths, fairy tales, and legends, these tales also touch upon human life and existence and other non-religious facets of culture.

Observing the historical context of the folktales about apparent death reveals the extent to which the tales have been shaped by the evolution of medicine, early developments in journalism and the literary fiction that was popular in its time.

\section{ACKNOWLEDGEMENTS}

The article was written within the framework of the research project "Narrative and belief aspects of folklore studies" (EKM 8-2/20/3), and was supported by the European Union through the European Regional Development Foundation (the Centre of Excellence in Estonian Studies, CEES, TKK 145).

\section{ARCHIVAL SOURCES}

RKM - Folklore collection of the Estonian Folklore Archives 


\section{NOTES}

1 See https://www.kliinik.ee/haiguste_abc/varjusurm/id-1969, last accessed on 9 December 2020.

2 Apart from influencing politics and the written press, the cofounders of the Society, William Tebb and Edward Perry Vollum, also published a rather popular book, titled Premature Burial and How It May Be Prevented, in 1896 (see Hartzman 2017).

3 A German translation was published soon after (1754).

${ }^{4}$ Christoph Wilhelm Hufeland wrote his thesis on Scheintod in 1783 . He was a kind of a typical Enlightenment scholar who, aside from studying signs of death, actively focused on educating lay people. His book of instructions, Die Kunst, das menschliche Leben zu verlängern (1798) was translated into Estonian in 1904 by H. Ilves under the heading Kunst, kuidas kaua elada võib (The art of prolonging life). The book presents various instructions on living a stress-free life, nutrition, hygiene, aging, and illnesses that have relevance even today.

5 The report comes from Urmas Oras, a nursing home cleric, who had heard it years ago from a woman born in the early twentieth century in Tartu nursing home.

6 The exact year when the hospital was opened varies in different sources. Valdeko Vende has suggested it was opened in 1865, while Heino Gustavson suggests the year 1869. Heinrichsen's foundation was used in the early twentieth century in an attempt to open another medical institution in Tallinn, although not a waiting mortuary but a hospital for the poor (see Vende 1990: 50; Gustavson 1979: 148, 204).

7 For example, in the type index of Russian folktales, the tale has the same type number and is titled 'A robber rescues a woman buried alive' (Заживо погребенную спасает грабитель), see Barag et al. 1979: 252-253.

8 This historical piece of fiction involving major international political figures has captured the attention of the local media on several occasions. Most recently, it was discussed on 9 October 2019 in the popular Estonian television programme Pealtnägija (Eyewitness), where the old tale was presented in a completely modern context. Here Friederike was introduced as the great-grandmother of current British Prime Minister Boris Johnson, who has played a major role in implementing Brexit (see Pihl 2019).

9 This claim is based on data in the database of Estonian newspapers DEA and DIGAR, and the files of the bibliography department of the Estonian Literary Museum.

${ }^{10}$ See the ALCOR Life Extension Foundation, available at https://alcor.org/, and the Wikipedia article at https://en.wikipedia.org/wiki/Alcor_Life_Extension_Foundation, both last accessed on 10 December 2020. See also Maaleht 2019. 


\section{REFERENCES}

Ariès, Philippe 1991. The Hour of Our Death. A Landmark History of Western Man's Attitudes toward Death - and Life - over the Last Thousand Years. New York: Oxford University Press.

Barag et al. 1979 = Barag, L.G. \& Berezovskii, I.P. \& Kabashnikov, K.P. \& Novikov, N.V. (comps.) Sravnitel'nyi ukazatel' siuzhetov: Vostochnoslavianskaia skazka. [A Comparative Index of Plots: East Slavonic Folktale.] Leningrad: Nauka. Available at http://www.ru-skazki.ru/barag-comparative-index.html, last accessed on 10 December 2020.

Bergengruen, Werner 1966. Surm Tallinnas. [Death in Tallinn.] Loomingu Raamatukogu no. 35. Tallinn: Perioodika.

Boccaccio, Giovanni 2004. Dekameron. [Decameron.] Transl. into Estonian by Johannes Semper. Tallinn: Tänapäev.

Bondeson, Jan 2001. Buried Alive: The Terrifying History of Our Most Primal Fear. New York \& London: W. W. Norton \& Company.

Eesti Postimees 1904 = Varjusurm. Prof. Obolenski järele. [Apparent Death. After Prof. Obolenski.] Eesti Postimees, a special extra on sciences, no. 73, p. 141.

Esmaspäev 1926 = Hirm elusalt maetud saada. Inglise lady, kes oma laibal laskis läbi lõigata kõri. [The Fear of Being Buried Alive: An English Lady Who Had Her Throat Cut After Death.] Esmaspäev: piltidega nädalleht, no. 39, 27 September. Available at https://dea.digar.ee/cgi-bin/dea?a=d\&d=esmaspaev19260927.2.31, last accessed on 10 December 2020.

Gustavson, Heino 1969. Meditsiinist vanas Tallinnas kuni 1816. a. [Medicine in Old Tallinn before 1816.] Tallinn: Valgus.

Gustavson, Heino 1979. Tallinna meditsiin XIX sajandist kuni 1917. a. [Medicine in Tallinn from the 19th Century to 1917.] Tallinn: Valgus.

Hartzman, Marc 2017. Proper Care for the Not-Quite-Dead-Yet: The London Association for the Prevention of Premature Burial. Weird Historian, 25 September. Available at http://www.weirdhistorian.com/proper-care-for-the-not-quite-dead-yet-thelondon-association-for-the-prevention-of-premature-burial/, last accessed on 10 December 2020.

Hufeland, Christoph Wilhelm 1904. Kunst, kuidas kaua elada võib / Dr. Hufelandi järele. ['The Art of Prolonging Life' after Dr. Hufeland.] Transl. into Estonian by H. Ilves. Laatre: H. Ilves (Viljandi: A. Tõllasepp).

Issakov, Sergei \& Peegel, Juhan 1998. Uusi andmeid esimese eestikeelse ajalehe kohta. [New Information on the First Estonian-language Newspaper.] In: Tõnu Tannberg (ed.) Tarto maa rahva Näddali-Leht: Uurimusi ja allikmaterjale. [Studies and Sources.] Tartu: Eesti Ajalooarhiiv \& Eesti Kirjandusmuuseum, pp. 133-156.

Kaljund, Hinge 2012. Printsessi mõrv Koluvere lossis. [The Death of a Princess in Koluvere Castle.] Tallinn: Canopus.

Kalmre, Eda 1988. Ühest elavast jutust. [On a Living Tale.] Kirjandusmuuseumi VII kevadsessioon. Ettekannete teesid. [The 7th Spring Session of the Estonian Literary Museum. Abstracts.] Tartu: Fr. R. Kreutzwaldi nimeline Kirjandusmuuseum, pp. 8-9. 
Köhler-Zülch, Ines 2001. Erzählungen über den Scheintod. Faktizität und Fiktionalität in medizinischen Fallberichten. In: Jürgen Beyer \& Reet Hiiemäe (eds.) Folklore und Tatsachenbericht. Tartu: Sektion für Folkloristik des estnischen Literaturmuseums, pp. 107-126.

Köhler-Zülch, Ines 2012. Jutustused varjusurmast: Faktid ja fiktsioonid meditsiinilistes juhtumikirjeldustes. [Tales about Apparent Death: Facts and Fiction in Medical Case Reports.] In: Reet Hiiemäe (comp.) Mis on Ühist Gilgamešil ja geeniuurimisel? Käsitlusi kultuurist ja usundist. [What Do Gilgamesh and Genetic Research Have in Common? Studies in Culture and Religion.] Tartu: EKM Teaduskirjastus, pp. 179-203.

Kündja 1883 = Rakverest. [From Rakvere.] Kündja, 17 August, no. 33.

Lang, Merike 2004. Matusekommetest Kirde-Eestis 19. sajandil ja 20. sajandi algul. [Funeral Traditions in Northeast Estonia in the 19th and Early 20th Century.] Mäetagused, Vol. 25, pp. 77-102. http://dx.doi.org/10.7592/MT2003.25.merikelang.

Lovejoy, Bess 2015. 10 Famous People Who Were Afraid They'd Be Buried Alive. Mentalfloss. com, 20 May. Available at https://www.mentalfloss.com/article/64180/10-famouspeople-who-were-afraid-theyd-be-buried-alive, last accessed on 11 December 2020.

Maaleht 2019 = Igavese elu külmkamber. [Eternal Life in a Freezer.] Maaleht, 3 October. Supplements: Festival for the Aged.

Martsoo, Stella 2007. Ravimitest 18. ja 19. sajandi eestikeelses kalendrikirjanduses. [On Medicines in the Eighteenth- and Nineteenth-century Estonian Calendar Literature.] Mäetagused, Vol. 36, pp. 7-34. http://dx.doi.org/10.7592/MT2007.36. martsoo.

Mikkor, Marika 1994. Surmaga seotud tavadest ersamordva külades Sabajevos ja Povodimovos. [Death-related Rituals in Erza-Mordvin Villages in Sabayevo and Povodimovo.] ERM-i aastaraamat XL. [Annals of the Estonian National Museum.] Tartu: Eesti Rahva Muuseum, pp. 153-189.

Mikkor, Marika 1995. Soikkola isurite matusetavad. [The Funeral Traditions of Izhorians in Soikkola.] Akadeemia, No. 9, pp. 1889-1927. Available at https://www.digar. ee/arhiiv/nlib-digar:101570, last accessed on 10 December 2020.

Lehtmets, Andres \& Elmet, Katrin 2013. Surmast arsti pilgu läbi. [Death through the Eyes of a Physician.] Seminar presentation. Available at https://www.etag.ee/ wp-content/uploads/2012/05/Andres-Lehtmets.pdf, last accessed on 10 December 2020.

Oma Maa 1928 = Õudne lugu minevikust. Ämm sulges sünnitaja minija puusärki. Rahvajutt Saaremaalt. [A Horrifying Story from the Past: The Mother-in-law Enclosed the Daughter-in-law in a Coffin. Folktale from Saaremaa.] Oma Maa, 4 December, no. 137.

Pihl, Anna 2019. Boris Johnsoni Eestis surnud vaaremast räägitakse siiani verdtarretavaid lugusid. [People Are Still Telling Blood-Curdling Tales about Boris Johnson's Grandmother, Who Died in Estonia.] Pealtnägija, 9 October. Available at https://menu.err.ee/990141/boris-johnsoni-eestis-surnud-vaaremastraagitakse-siiani-verdtarretavaid-lugusid, last accessed on 10 December 2020.

Postimees 1887 = Haapsalust. [From Haapsalu.] Postimees, 28 March, no. 14. 
Postimees 1926 = Kas surnud on tõesti surnud? [Are the Dead Really Dead?] Postimees, 7 June, no. 149. Available at https://dea.digar.ee/cgi-bin/dea? $\mathrm{a}=\mathrm{d} \& \mathrm{~d}=$ postimeese w19260607.2.47\&e=-------et-25--1--txt-txIN\%7ctxTI\%7ctxAU\%7ctxTA-------------, last accessed on 15 December 2020.

Postimees 1928a = Varjusurma tont. Muumiate ja tinakambri laipade vereproov. [The Spectre of Apparent Death: Blood Tests on Mummies and Corpses in the Lead Chamber.] Postimees, 30 April. Available at https://dea.digar.ee/cgi-bin/dea?a=d \&d=postimeesew19280430.2.45\&e=-------et-25--1--txt-txIN\%7ctxTI\%7ctxAU\%7c txTA----------, last accessed on 15 December 2020.

Postimees $1928 b=$ Lõpp varjusurmale. Inimelektri ime. [An End to Apparent Death: The Miracle of Human Electricity.] Postimees, 7 May.

Reiman, Helmi 1915. Eestlaste matusekombed. [Estonian Funerial Customs.] In: Villem Reiman (comp.) Eesti Kultura, 4. Jurjev: Postimehe Kirjastus, pp. 123-163. Available at https://www.digar.ee/arhiiv/et/kollektsioonid/43920, last accessed on 15 December 2020.

Rimpiläinen, Olavi 1971. Läntisen perinteen mukainen hautauskäytäntö Suomessa ennen Isoavihaa. [The Funeral Practices of the Western Tradition in Finland before "the Great Discord" Period.] Suomen Kirkkohistoriallisen Seuran Toimituksia 84. Helsinki: SKS.

Rosenplänter, Johann Heinrich 1823. Ueber Kirchhöfe und Beerdigung der Todten, nebst einem Anhange den Pernauschen Kirchhof betreffend. Pernau: Gedruckt bey Gotthardt Marquardt. Available at https://www.digar.ee/arhiiv/en/nlibdigar:329323, last accessed on 10 December 2020.

Simonsuuri, Lauri 1987. Typen- und Motivverzeichnis der Finnischen Mythischen Sagen. FF Communications, No. 182. Helsinki: Suomalainen Tiedeakatemia.

Slack, Paul 1985. The Impact of the Plague in Tudor and Stuart England. London: Oxford University Press.

Tannberg, Tõnu (comp.) 1998. Tarto maa rahva Näddali-Leht: Uurimusi ja allikmaterjale. [Studies and Sources.] Tartu: Eesti Ajalooarhiiv \& Eesti Kirjandusmuuseum.

Uther, Hans-Jörg 2004. The Types of International Folktales. A Classification and Bibliography. Part I Animal Tales, Tales of Magic, Religious Tales, and Realistic Tales with an Introduction. FF Communications, No. 284. Helsinki: Academia Scientiarum Fennica.

Vende, Valdeko 1990. Ununenud Tallinn. [Forgotten Tallinn.] Tallinn: Perioodika.

Warner, Elizabeth A. 2000. Russian Peasant Beliefs and Practices Concerning Death and the Supernatural Collected in Novosokol'niki Religion, Pskov Province, Russia, 1995. Part I: The Restless Dead, Wizards and Spirit Beings. Folklore, Vol. 111, No. 1, pp. 67-90. https://doi.org/10.1080/001558700360898.

Wirulane 1884a = Kaks korda surnud. [Dead Twice.] Wirulane, 20 March, no. 12. Available at https://dea.digar.ee/cgi-bin/dea?a=d\&d=wirulane18840320.2.8\&e=-----et-25--1--txt-txIN\%7ctxTI\%7ctxAU\%7ctxTA------------, last accessed on 15 December 2020.

Wirulane 1884b = Eesti maalt: Tallinnast. [From Estonia: From Tallinn.] Wirulane, 17 April, no. 16. Available at https://dea.digar.ee/cgi-bin/ dea?a=d\&d=wirulane18840417\&e=-------et-25--1--txt-txIN\%7ctxTI\%7ctxAU\%7 ctxTA------------, last accessed on 15 December 2020. 
Eda Kalmre is Senior Research Fellow $(\mathrm{PhD})$ at the Department of Folkloristics of the Estonian Literary Museum, Estonia. Her main fields of interest are contemporary legends and rumours and storytelling, aspects of memory and history in folk narratives, relations between legends, rumours, and media.

eda.kalmre@folklore.ee 